\title{
Competency Management in the Context of Omani Civil Service Reform \& Development
}

\author{
Ahmed Albalushi ${ }^{1}$, Ashraf Zaidan ${ }^{2,}$ Fakhrul Adabi Bin Abdul Khadir ${ }^{2}$, Muhammed Bin Yusof ${ }^{2}$ \\ ${ }^{1} \mathrm{PhD}$ student in Human Development at University of Malaya, Malaysia \\ ${ }^{2}$ Dr., Senior Lecture in Department of Dakwah \& in Human Development at University, Malaysia \\ Correspondence: Ahmed Albalushi, PhD student in Human Development at University of Malaya, Malaysia.
}

\author{
Received: February 1, 2019 \\ Accepted: March 15, 2019 \\ Online Published: March 20, 2019 \\ doi:10.5539/ibr.v12n4p76 \\ URL: https://doi.org/10.5539/ibr.v12n4p76
}

\begin{abstract}
This paper aims to discuss the extent of the application-based management efficiency in the Sultanate of Oman Civil Service, by comparison with the practices and experiences of five systems of the civil service or the public in each of the (United States of America, Canada, South Korea, Saudi Arabia, United Arab Emirates). Several variables and address are necessary to achieve reform and development in the civil service such as the situation organizational and strategic system competencies, selection and appointment and based on efficiency, performance evaluation based on efficiency as one of the main functions of human resources management in the public sector, and the framework or efficiency model. In order to become a civil service in Oman of the best practices in the efficient management system at the regional and international level, providing more than ten developmental proposals paper to raise the level of the civil service, because the competency's management of important topics in the development of civil service performance, seen as a tool to shift from the traditional bureaucracy to modern organizations.
\end{abstract}

Keywords: competency management, competencies, civil service, development in public sector

\section{Introduction}

\section{Introduce the Problem}

A recent study by the (Korn Ferry, 2018) Entitled: Global Talent Crisis The Global Talent crunch By studying the financial implications resulting from the lack of qualified owners at three different time levels 2020.2025, 2030 (20) of the economies of developed and developing countries where the study results that there is a major crisis looming enormous shock will affect the institutions all over the world, it is expected a shortage of skilled labor by the year 2030, it has a talent crisis lead to a change in the global balance of economic power by 2030 and must governments take different methods and approaches to meet the expected shortfall in talent. The translation of those directives of the Sultan of Oman came to be prepared for future vision" Oman 2040" So as to be assimilated to all sectors and forward-looking and focus of the vision: develop competencies and improve the effectiveness of governance and institutional performance (Oman 2040, nd).

He stressed (Gangani, et al, 2006) That the use of the efficient method as the basis for the management and development of human resources has become widespread and is gaining more international practices, therefore it must be more research on the applicability of competencies in various HR functions. This is what makes public administration systems around the world have Undergone major reforms over the past twenty years and is likely to continue to change in the future and assumes that the management competencies are supporting this process of change, as seen as a pressure tool to shift from the traditional bureaucracy to the flexible and modern organizations De Beeck and Hondeghem, 2010).

In line with future developments and changes rapidly, the article will focus on the study of human resources in the Sultanate of Oman Civil Service system, compared with some government practices in some of the world applied to those systems. Because talent management has become one of the most important practices in government and private institutions, they help those organizations identify the right person to work, and other basic functions of human resources (Draganidis \& Mentzas, 2006). Confirms (SO De Beeck \& Hondeghem, 2010) that is expected when the civil servants apply competencies in their work, the result is to be the effective performance, which in turn leads to the achievement of the objectives of the government. And thus, the positive impact on the economic 
growth of the countries when adhering to the principles of merit in the civil service (Cortázar, JC, 2016).

The construction of an integrated system for the management of competencies is important to move to a talent nment management system steps, and if implemented properly it will achieve the best results of gover performance, and promotes the competitiveness of the public sector, and improves government services, and to achieve justice among employees. We hope to take the proposals contained in this article effectively, and that re research and studies in talent management and talent in the public sectorefforts are harnessed to do mo.

\section{Method}

Because of the overlap of public administration (government) in many areas, and connections to many fields of knowledge, it has numerous studied ways, there became different approaches to study, including comparative entrance, and by comparing systems and processes of public administration in two or more countries (Ali, et al., 2013). Where the focus of public administration comparison Comparative Public Administration (CAP) Governments on how to manage resources from a comparative perspective, so increased recently the emergence of a group of international reports issued by the Organization for Economic Cooperation and Development (OECD) Or from the World Bank (The World Bank) And other organizations that focus their reports on international comparisons, where it turned out that $13.6 \%$ of the articles dealing with the public administration are from a comparative perspective (Walle \& Brans, 2018). Points (Okoth \& Ph, 2015) that there is a dearth of literature on public administration in general in the Arab Gulf states, as most of these countries tend to borrow best practices.

Given the importance of comparative studies in the field of public administration, this article will discuss some of the practices related to talent management system in six different countries around the world, (the United States of America, Canada, South Korea, Saudi Arabia, Oman, in addition to the Sultanate of Oman) through access to the literature, international and published reports, laws and regulations governing the system of competencies in those countries and policies, in order to stand closely to develop talent management practices in the civil service sector in Oman, and compared with selected countries, out the results and recommendations contribute to raising the efficiency of the Wireless Performance Government and achieve the future vision of Oman 2040.

The reason for the identification of Arab States for the rest of the region, the great similarity in the civil service system in terms of legislation and the stages of establishment and development, and adopting efficiency mainly in the selection and recruitment in government jobs, and because human development in the GCC levels converged as in the human development of the United Nations Report (United Nations, 2013). And practices of foreign countries have been selected based on a recent study conducted by the Organization for Economic Cooperation and Development (OECD) In 2009 where it was found that these mature experiences with efficient management system states (SO De Beeck \& Hondeghem, 2010). In addition to being one of the most effective in government effectiveness indicator governments Government Effectiveness Index Issued by world Resource Institute Which measures the quality of public services provided, and the level of qualification of civil servants, and the independence of the civil service (World Resource Institute, 2008).

\section{Scientific Theory \& Study Variables}

In 1982 the scene came in administrative and organizational studies (Richard Boyatzis)So he studied the relationship between efficiency and job performance through " Model of Effective Job Performance" Which was based on the effective impact and get the performance will happen when the three critical components are compatible or suitable with each other, namely: (individual competencies, organizational environment, and requirements functional), and if not be compatible with each other will then happen behavior is ineffective or inaction about job(Boyatzis, 1982). And subsequently published McClelland (1973)Famous essay related to acceptance tests to fill jobs in the US State Department, which aimed to identify the common characteristics enjoyed by not Elite enjoyed by others and devised a list of characteristics (competencies) that called (efficiency model). Studies and applications based on efficiency since that time and then gained to the present acceptance among the academic work and the business community have gone through three stages of development (Kupczyk, 2014) :

1- The first stage: Competencies Individuals Both researchers(White 1959; McClelland 1973; Boyatzis 1982; Woodruffe 1992; Spencer, Spencer 1993; McCracking 1998)

2- The second phase: Competencies Models For each of the (Mansfield 1996; McLagan 1997; Lucia, Lepsinger 1999; Rothwell, Lindholm 1999).

3- third level: Core Competency Identifying, For each of the (Prahalad, Hamel 1990; Ulrich, Lake 1991; 
Gallon, Stillman, Coates 1995; Coyne, Hall, Clifford 1997; Rothwell, Lindholm 1999; Delamare, Winterton 2005

According to the theoretical assumptions, the efficiency-based management is a new trend in human resources management and is one of the advantages of building competency's management systems in the possibility of integrating all areas of human resources management because of a methodology based on efficiency(Sienkiewicz, 2014). Confirms(S. Beeck \& Hondeghem, 2010) That talent management is more than just identifying competencies and using them in different processes of human resources, as they need to be dynamic on the organization as a whole and should be talent management becomes a way of thinking for their integration into human resources activities and systematically, and in line with the organization, vision and strategic message and implemented throughout the organization.

And we will adopt in this paper on the study of three variables, namely, (organizational and strategic position of the system of competencies, and functions of human resources management based on efficiency and focus only on those two practices, namely selection, recruitment and performance evaluation, the last variable is the frame or efficiency model) and compared between the civil service systems or the public in six different countries. And Figure 1 shows an integrated system for the management of competencies in the organization, where vertical integration refers to human competency's coherence with the vision and strategy of the organization, as well as human resources policies, therefore should be selected competencies, organize, develop and evaluate even contribute to the achievement of the organization's goals.(S. Beeck \& Hondeghem, 2010).

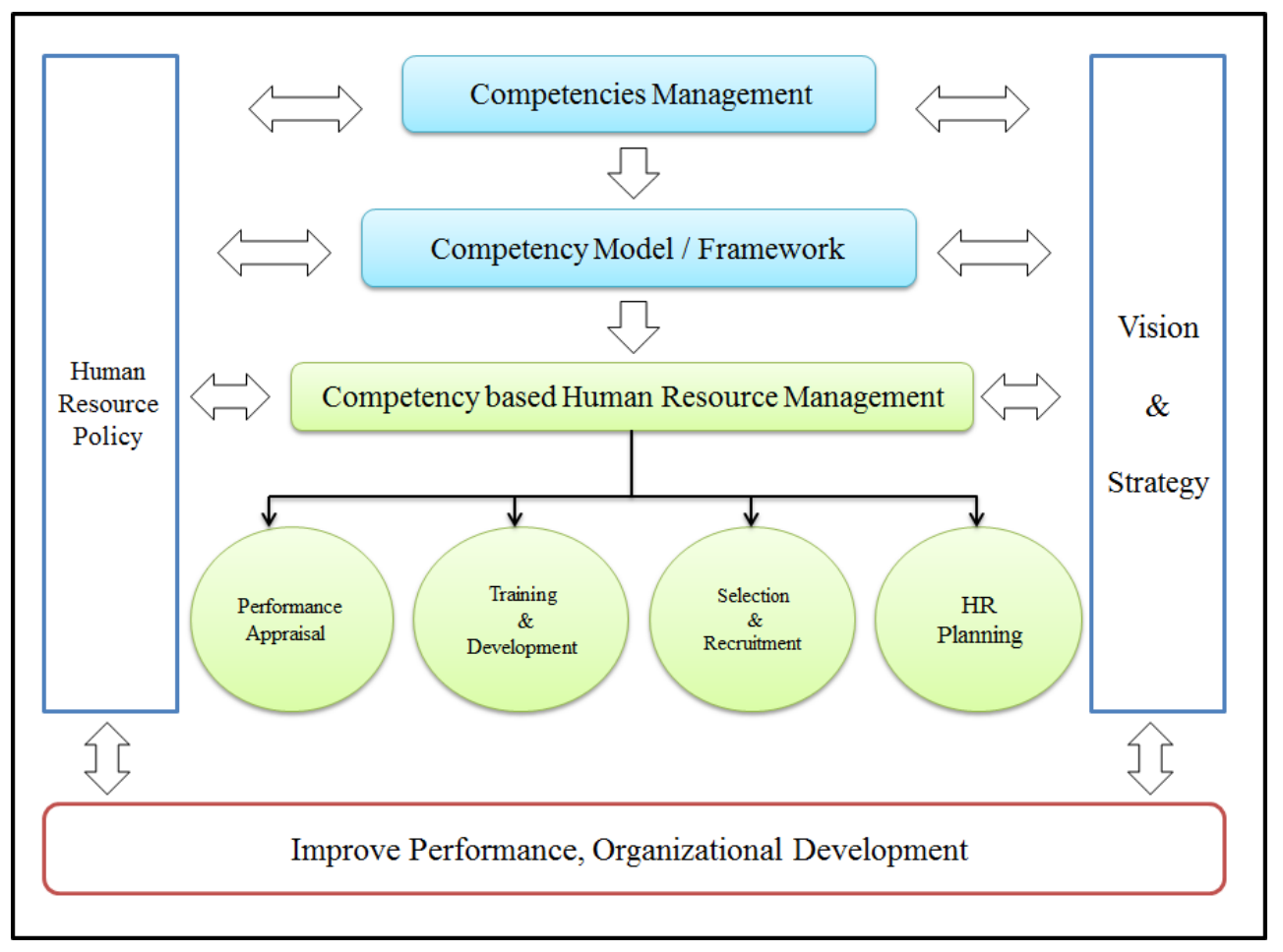

Figure 1. Competencies Management System (L. Spencer, \&S. Spencer, 1993), (Laakso-Manninen \& iitala, 2007), (S. Beeck \& Hondeghem, 2010), (Campion \& Odman, 2011)

\section{Background}

One of the most major challenges for the management of human resources based on efficiency is that the concept of efficiency is precisely defined and can be understood in different ways (Sienkiewicz, 2014). The term efficiency is scientifically and practically both for its association with a wide range and variety of meanings and terms ability, aptitude, capability, competence, effectiveness, and skill This can be a term attributed to individuals, or groups, or institutions, and because of the Tapping in scientific definitions of efficiency, it is impossible to determine a specific definition agreed upon, however, it can be explained through scientific or process that followed the researcher to build the scientific theory of efficiency goals (Weinert, 1999) (Delamare, Deist, and Winterton, 2007). Where it can be returned term efficiency the term competency in the literature to the 
seventies, there are many different definitions of efficiency (Benayoune, 2017).

McClelland (1973)"Competency is defined as a personal trait or set of habits that lead to more effective or superior job performance". L. Spencer, \& S. Spencer (1993) "Competencies are skills \& abilities-things you can do-- acquired through work experience, life experience, study or training ".Draganidis, F., \& Mentzas, G. (2006" Competency is a combination of tacit and explicit knowledge ,behavior and skills that gives someone the potential for effectiveness in task performance".

The definition of the latter confines us to a comprehensive definition that has been reached after the study and analysis of twelve definitions of efficiency.

Reached L. Spencer, \& S. Spencer (1993) To five properties for efficiency named "The Iceberg Model "Where many institutions to choose on the basis of competencies phenomenon Visible part (Knowledge, Skills) If, for example, said: We postgraduates of the best colleges and then assume that they have the competencies Batinah Hidden part (Self-concept, Trait, Motive) Or it can install these features through good management, but it is likely to be the opposite is economically feasible, for institutions to choose to accord to the competencies of internal medicine and the training competencies phenomenon. Concluded Timothy, Athey.M, Orth (1999) Through his study of the concept of efficiency that there is a set of similar characteristics which distinguish it from other concepts, including: knowledge or skills associated with current job performance; emerging knowledge or skills required for future success; intellectual or behavioral best practices of high performing people or teams; process capabilities that enhance organizational or business performance; new ways of thinking or behaving that provide the distinctive competitive advantage. The talent management sometimes called-based management efficiency competency-based management Includes identifying competencies that distinguish high performers from the average performance in all organizational areas and build a framework of competencies and use it as a basis for selection and recruitment, training and development, rewards, and various other aspects related to personnel of the Organization(De Beeck \& Hondeghem 2010). Conducted Aberdeen, Group (2007) A leading international institution in the field-based research on the labor market, a study in (370) Organization of the world about the extent of use and application management competencies and benefits from the application of management initiatives based on efficiency, and highlighted the findings of the study: that $66 \%$ Organizations use seminars and training sessions method as part of their efforts and initiatives in talent management, and $41 \%$ of organizations have models of efficiency, and that $57 \%$ of those organizations reported that the harmonization between the workforce and the goals of the organization, is the main factor that drives to focus on the adoption of talent management and that there is a strong correlation between the management of competencies and the ability of the organization to improve workforce productivity.

\section{Organizational and Strategic Competency's System Status}

Research suggests that States that are managed by skilled enjoying high economic growth rates, and this confirmed it as well World Development Report 1997 That the application of merit Merit In the civil service helps to bring staff with high quality. (UNDP, 2015).

Civil service systems or public around the world seek to apply the principles and systems of effective management in all public functions, which result in the presence of government agencies responsible supervision and regulation and the development of policies and systems that achieve the goals of public administration seeks to achieve efficiently and effectively.

These devices differ in terms of the nature of the supervision and terms of reference and titles, but they are divided into two main, namely: 1 . The first type: central single device, and entrusted to him all the terms of reference for the management of public office, whether legislative or executive and be their subordination in the habit of the highest authority in the country such as the Council of Ministers, such as

Federal Authority for Government Human Resources (FAHR) in Emirates, \& Public Service Commission (PSC) in Canada, \& Ministry of Personnel Management (MPM) in South Korea.

2- The second type is central, there is more than one distributed among them terms of reference, so the two sides, as is the case in Oman Saudi Arabia (Civil Service Council As a legislative and Ministry of Civil Service As an executive) or may consist of three sides, as in United States Which Office of Personnel Management (OPM) And specializes issuing legislation and to provide guidance and counselling, and Merit Systems Protection Board (MSPB) As a quasi-independent judiciary to protect the federal merit of banned practices and protect government employees from management systems violations, and Federal Labor Relations Authority (FLRA) Which seeks to bring stability and closer working relationships thereby contributing to achieving the highest levels of government performance. 
a special committee is known as the Commission Northcote Trevelyan 1854 to study personnel. The United States did not lose sight of that, we're not only Msalhawwa the US government in the late nineteenth century, the use of only European experience, but they were also fond of saying: The acquisition of those systems is a necessary step in the direction of enlightenment if they wish to develop and become a civilized nation, and the first steps have been taken to find a modern management is to establish a civil service system is the appointment and take positions based on merit (Shafritz, \& Hyde, 2012). In Canada, in 1962 report recommended Royal Commission on Government Organization The need to provide public services in government in both English and French and to rename the Civil Service Commission for the name of the Public Service Commission shall be responsible for the recruitment and training and development programs. The big shift in the Canadian government in the civil service system was in 2003, where it was issued and amending several laws, legislation and policies into law the Public Service Act and the values and ethics of public servants, and the granting of powers to Public Service Commission. In 2009, he announced the Canadian Prime Minister made significant structural in human resources management in the public service changes more coherent, streamlined and effective way to make it, and by enabling deputy ministers to assume responsibility for human resources in their departments, and streamlining the roles of the central agencies of human resources, and make adjustments to the policy General, and to clarify responsibilities and eliminate duplication. (Hurley, J, 2017, Lynch, KG, 2009).

England was the world leader in the introduction of a system of merit as it formed an

As South Korea has faced in 1997 economic crises, including the inadequacy of the competitiveness of the government compared to the private sector because of the low civil service performance level, so the government began to enter many of the reforms has shown the presidency Kim Dae Jung(1998-2002), which called for which to create a small and effective government, but they offer the best service and part of the reforms undertaken by the Government to strengthen the role of human resources and the creation of a workforce's ability to be more competitive. In 2001, the application of talent management in the system of government which has been designed to support human resources planning, including operations began the selection, promotion, training and career advancement, as part of the reform strategies and improve government performance, which aims to improve and raise the civil service efficiency and thus enhance the competitiveness of South Korea. (De Beeck \& Hondeghem, 2010, Namkoong, K, 2007).

The first effort to reform the administrative system in Saudi Arabia was in 1927 under the name of "inspection committee and reform", and in 1931 issued the first civil service system, and with the expansion of the government apparatus and the diversity of fields used the government in 1960, a group of World Bank experts and the Ford Foundation of America to conduct a study on Situation of public administration, as a result of economic growth witnessed in the Kingdom in the seventies of the last century, passed the current civil service system, and the system of the Civil Service Council, and the establishment of the General Personnel Council, which later turned to the Ministry of Civil Service in 1999. ( Rashid, 2004).

In the Sultanate of Oman have been assigned Civil Service Affairs in 1970, the Ministry of Royal Court Affairs, and in 1975 issued the first law to regulate the administrative apparatus and the first civil service law, and in 1988 was the establishment of the Ministry of Civil Service and the formation of the civil service means the development of public policies on matters of public office, in 2004 the Civil Service Law and the applicable issued so far.

In the UAE, the Civil Service Law was promulgated in the Federal Government in 1973 and the formation of the Civil Service Council, and in 2001 was the establishment of the Civil Service Bureau follows the Civil Service Council, and in 2008 was the establishment of the Federal Authority for Government Human Resources and the issuance of the Human Resources Act.

After studying the organizational status of the system of qualified human resources in the Arab and foreign countries, comparison shop, and the reforms and the changes made by these countries in order to consolidate the principles of efficiency in the public service, we conclude that there are some foundations and principles that must be based on talent management in the public sector system, As follows :

1- That efficiency has become linked to the public service, and must be linked as well as policies, laws and regulations and procedures for recruitment, training, performance evaluation and other key functions related to human resource's management. Thus, became the logical model work efficiency prominent and important for the diagnosis and supervision and improve leadership in general, and the management of human resources (Prasanthi, S, 20015).

2- All states have varying practices in the civil service systems, it must be the pursuit of continuous updating of these systems in order to cope with the requirements of each stage. Where is the reform of the civil service of 
the most difficult development reforms, but it is now essential for the sustainability of the public sector because the application of the principles of merit in the civil service gives the individual the ability to achieve the best results, which reflected positively on the well-being of society(UNDP, 2015, 2010).

3- The shift from the traditional role to a strategic role in the civil service. The International Public Management Association for Human Resources (IPMA-HR) Establish a working group of experts to discuss the challenges and opportunities facing human resources in the public sector for the year 2020, and the findings of the Panel that the majority of human resources departments in the public sector suffers from a lack of support, expertise and resources needed to achieve the transition from the role of actions to the strategic role and innovation and strategic direction contribute to the success of human resources and turn them into an effective strategic partner rather than as a tool for action and to provide assistance. (IPMA-HR, 2016). For example, putOPM A strategic plan until the year 2022 (OPM, 2018) As well as FAHR Developed a strategic plan until the year 2021 FAHR, 2017).

4- Broad participation and benefit from applied research and best practices while doing the preparation and development of competencies system in the civil service. For example, the Canadian government has adopted a management framework based on efficiency Competency-based Management for a year 1999Through the allocation of a specialized committee which is the Steering Committee on Management based on the efficiency, where the Commission in consultation with officials of the Treasury Board and the Public Service Commission, the Joint Committee between the concerned departments administering the efficiency, the Council of Human Resources, and representatives of the staff, the Committee also adopted on practical experience, and management practices that have been applied over the past few years, and the results of research conducted in the public and private sector institutions that have implemented human resources management system based on efficiency, and conduct a field study on 57 government institution Federal Of Canadian. As well as is the case for South Korea, where the participants in the preparation and implementation of the competency model of senior civil service officials, experts from the Korean Society for Organizational and Industrial Psychology, Society for Korean personnel management, and a group of consultants, and officials from the Civil Service Commission, and the staff of human resources departments in government ministries and agencies, and the completion of the work has been used several methodologies, such as the analysis of jobs, and in-depth interviews and questionnaires, as well as in-depth review of the literature of talent management in general and in particular models of efficiency(De Beeck \& Hondeghem 2010).

To activate the organizational and strategic competencies system in the civil service situation in Oman in the light of previous comparisons, they need attention and make a study of the proposed reforms referred to in Table (1).

Table 1. the proposed civil service reforms in Oman to activate the organizational and strategic position of the system of competencies

\begin{tabular}{|c|c|c|c|c|}
\hline $\mathrm{M}$ & The proposed reforms & Implementation & up-Follow & $\begin{array}{l}\text { Take advantage of the practices } \\
\text { and methodologies }\end{array}$ \\
\hline .1 & $\begin{array}{l}\text { velop a strategic plan for the civil De } \\
\text { service competencies in line with the } \\
\text { vision of Oman } 2040\end{array}$ & $\begin{array}{l}\text { Ministry of Civil } \\
\text { Service }\end{array}$ & $\begin{array}{l}\text { Civil Service } \\
\text { Council }\end{array}$ & (OPM, 2018), (FAHR, 2017) \\
\hline .2 & $\begin{array}{l}\text { The development of strategic objectives } \\
\text { of competencies in all of the civil service } \\
\text { authorities }\end{array}$ & All sides & $\begin{array}{l}\text { Ministry of } \\
\text { Civil Service }\end{array}$ & $\begin{array}{l}\text { Center for Innovation in Public } \\
\text { Service (HCM } \text { Framework), } \\
\text { Competency based } \\
\text { (PSC) }\end{array}$ \\
\hline .3 & $\begin{array}{l}\text { General policies of the preparation of } \\
\text { competencies }\end{array}$ & $\begin{array}{l}\text { Ministry of Civil } \\
\text { Service }\end{array}$ & $\begin{array}{l}\text { Civil Service } \\
\text { Council }\end{array}$ & $\begin{array}{l}\text { Policy (MPM), Public policy \& } \\
\text { HRD (United Nations, 2005). }\end{array}$ \\
\hline .4 & $\begin{array}{l}\text { The development of training plans and } \\
\text { conduct applied research and management } \\
\text { consulting competencies in the } \\
\text { management system }\end{array}$ & $\begin{array}{l}\text { Institute of Public } \\
\text { Administration }\end{array}$ & $\begin{array}{l}\text { Ministry of } \\
\text { Civil Service }\end{array}$ & $\begin{array}{l}\text { HR University (OPM), Canada } \\
\text { School of Public Service. }\end{array}$ \\
\hline
\end{tabular}

\section{Recruitment \& Selection System - Based Competency}

The selection and appointment process Recruitment \& Selection Of the most important departments of personnel management functions and the most serious and sensitive, being a task that is determined through which to exclude individuals who are less efficient, Through this process, determined the future of the civil service and the level of efficiency and effectiveness of staff (Alkubaisi, Amer, 2005) .According to the results published by the The National Business Research Institute For the year 2014 That employment is not effective can cost the institution 25 one thousand dollars, And sometimes lead to leave their jobs for new employees during the first six months due to the ineffectiveness of the selection and recruitment procedures (Peregrin, 2014)( Rosenberg, 
2000). Confirms. Spencer, \& S. Spencer (1993) That the selection methods of appointment based on efficiency based on the following hypothesis: "The greater the compatibility between the job needs and competencies of the holder, increased work performance and job satisfaction."

We would like to mention that the civil service systems in the countries comparison shop has taken the methodology of efficiency as a basis for the selection and access to public office, but there is a difference in how to apply the methodology through the use of tools or means of employment, organizational levels that are subject to the procedures, and the required number of stages for the selection of individuals with efficiency. And Table 2 shows some of the selection practices based on efficiency in countries comparison shop appointment.

Table 2. based on the comparison between the selection and recruitment practices on efficiency

\begin{tabular}{|c|c|c|c|c|c|c|}
\hline Comparison & $\begin{array}{l}\text { (OPM) } \\
\text { USA }\end{array}$ & $\begin{array}{l}\text { (PSC) } \\
\text { Canada }\end{array}$ & $\begin{array}{l}\text { (MPM) } \\
\text { S. Korea }\end{array}$ & $\begin{array}{l}\text { (MCS) } \\
\text { KSA } \\
\end{array}$ & $\begin{array}{l}\text { (FAHR) } \\
\text { UAE }\end{array}$ & $\begin{array}{l}\text { (MCS) } \\
\text { Oman }\end{array}$ \\
\hline $\begin{array}{l}\text { Functional grades are subject } \\
\text { to a system of open } \\
\text { competition }\end{array}$ & All grades & All grades & and 97,3 & $\begin{array}{l}\text { and } 7,8 \\
6\end{array}$ & specific-Non & $\begin{array}{l}\text { Typical } \\
\text { functions and } \\
\text { support } \\
\text { services }\end{array}$ \\
\hline $\begin{array}{l}\text { leadership of the Is the } \\
\text { system are subject to open } \\
\text { competition levels }\end{array}$ & Yes & Yes & Yes & No & No & No \\
\hline $\begin{array}{l}\text { Methods and tools for } \\
\text { selection and appointment }\end{array}$ & $\begin{array}{l}\text { Exam \& } \\
\text { Interview }\end{array}$ & $\begin{array}{l}\text { Exam \& } \\
\text { Interview }\end{array}$ & $\begin{array}{l}\text { Exam \& } \\
\text { Interview }\end{array}$ & Exam & Exam \& Interview & Exam \\
\hline $\begin{array}{l}\text { Does the selection system is } \\
\text { to a frame or linked } \\
\text { appointment } \\
\text { competencies model }\end{array}$ & Yes & Yes & Yes & No & Yes & No \\
\hline $\begin{array}{l}\text { Otmmh } \\
\text { electronically }\end{array}$ & $\begin{array}{ll}\text { At } & \text { all } \\
\text { stages } & \end{array}$ & $\begin{array}{ll}\text { At } & \text { all } \\
\text { stages }\end{array}$ & - & $\begin{array}{l}\text { At all } \\
\text { stages }\end{array}$ & $\begin{array}{l}\text { Electronic } \\
\text { submission and in } \\
\text { the screening stage }\end{array}$ & At all stages \\
\hline $\begin{array}{l}\text { Is there evidence of the } \\
\text { system are indicative of } \\
\text { selection and appointment }\end{array}$ & Yes & Yes & Yes & No & Yes & No \\
\hline $\begin{array}{l}\text { Is there a mechanism for } \\
\text { grievance procedures of } \\
\text { selection and appointment }\end{array}$ & Yes & - & - & No & No & No \\
\hline
\end{tabular}

Source: (Cho, 2010), (Kim, S, 2010), (PSC, 2017), (Sabbarah, 2013), (MPM, 2018), (MSPB, 2004, 2017), (OPM, nd), (OCHRO 2015).

The previous table (2) note that:

1- Oman, Saudi Arabia and the UAE agree to exclude senior leadership positions from the civil service open competition and applied to the rest of the jobs. : A study of the World Bank and experts involved in the performance of the public sector that senior government positions require skills and competencies, and therefore requires efforts in the polarization and keep them in accordance with the competency management system, has allocated some countries and the independence of that category under the name Senior Executive Civil Service As in America, Canada, Britain, South Korea, Australia, and the choice of appointment system and a competitive open document on merit (Lafuente, M. et al, 2012 ). A study OECD (2015): That half of the EU member states have a competency framework for senior civil servants is used in recruitment and training.

2- $\quad$ Selection and appointment system is linked to a framework or model competencies in both America and Canada, South Korea and the UAE. Confirms Sienkiewicz (2014) That the successful application of the concept of competencies in the organization conditional on providing practical in the field-based human resources management solutions on efficiency through efficiency models or frameworks.

3- Selection and appointment guide is one of the important tools that help managers and HR staff in understanding the processes and procedures related to employment, which is present in both America and Canada, South Korea and the UAE.

4- And procedures for selection and recruitment operations in Oman and Saudi Arabia is somewhat similar.

In light of the previous comparisons, we suggest some reforms for employment based on the activation of efficiency as in Table 3. 
Table 3. the proposed civil service reforms in Oman to activate employment based on efficiency

\begin{tabular}{|c|c|c|c|c|}
\hline $\begin{array}{l}\text { Take advantage of the } \\
\text { practices and } \\
\text { methodologies }\end{array}$ & Implementation & preparation & The proposed reforms & $\mathrm{M}$ \\
\hline $\begin{array}{l}\text { (MSPB, 2004, 2017), } \\
\text { (OPM, nd), }\end{array}$ & $\begin{array}{l}\text { Civil Service } \\
\mathrm{h} \text { the Council wit } \\
\text { Council of Oman }\end{array}$ & $\begin{array}{l}\text { Joint work between the } \\
\text { Ministry of Civil Service } \\
\text { and government agencies } \\
\text { team }\end{array}$ & $\begin{array}{l}\text { special Modifying the texts of the } \\
\text { selection and appointment of legal } \\
\text { materials in the Civil Service Act and its } \\
\text { implementing regulations so based on } \\
\text {.the principles of efficiency }\end{array}$ & .1 \\
\hline $\begin{array}{l}\text { (MPM, 2018), (PSC, } \\
\text { 2017) }\end{array}$ & $\begin{array}{l}\text { Civil } \\
\text { Council }\end{array}$ & $\begin{array}{l}\text { Joint work between human } \\
\text { resources experts and the } \\
\text { Ministry of Civil Service } \\
\text { Team }\end{array}$ & $\begin{array}{l}\text { Public policy for employment in the } \\
\text { civil service preparation }\end{array}$ & .2 \\
\hline $\begin{array}{lr}\text { Personnel } & \text { Psychology } \\
\text { Centre } & \text { (PSC, } \\
\text { Canada), } & \text { (Sabbarah, } \\
2013) & \end{array}$ & Council of Ministers & $\begin{array}{l}\text { The Ministry of Civil } \\
\text { Service and the Institute of } \\
\text { Public Administration }\end{array}$ & $\begin{array}{l}\text { The establishment of the National } \\
\text { Center for competency assessment }\end{array}$ & .3 \\
\hline $\begin{array}{l}\text { (MPM, 2018), (PSC, } \\
\text { 2017), (OPM, nd), }\end{array}$ & $\begin{array}{c}\text { Ministry of Civil } \\
\text { Service }\end{array}$ & $\begin{array}{l}\text { The Ministry of Civil } \\
\text { Service in cooperation } \\
\text { with the Institute of Public } \\
\text { Administration }\end{array}$ & $\begin{array}{l}\text { Preparation indicative evidence for the } \\
\text { selection and appointment }\end{array}$ & .4 \\
\hline
\end{tabular}

\section{Performance Appraisal System - Based Competency}

Used many organizations efficiency models as a basis for building performance management systems, and determine usually between five to ten core competencies be linked to the strategic objectives and factors of the success of the organization, it is advisable not to include a large number of competencies so as not to waste officials and management time in the procedures and evaluation stages, which Ansehm focus on the performance aspects of the employee (Pulakos, 2004). Where the report noted OECD (2017) That all OECD countries have assessments formal performance and mandatory for the staff of the central government, as agreed about 16 countries that staff performance management intervention in government areas of reform, where he was recently in Canada, the implementation of new systems in performance management and standardization of those systems for all federal public service employees, and occupied Korea South fourth place, the United States ranked fifth, Canada ranked 13th in the extent of the use of performance assessments in decisions related to human resources in the central government of the 37 countries of the OECD member countries index.

Since many different performance evaluation systems, but the recent trends of the system must be based on linking employee performance objectives and strategy of the organization, and to link the results of the evaluation and other functions for the management of human resources, as well as to enhance and develop the capabilities and competencies of staff. And Table 4 compares performance evaluation in countries comparison shop systems. 
Table 4. Comparison of the procedures used in the performance appraisal system

\begin{tabular}{|c|c|c|c|c|c|c|}
\hline $\begin{array}{l}(\mathrm{MCS}) \\
\text { Oman }\end{array}$ & $\begin{array}{l}\text { (FAHR) } \\
\text { UAE }\end{array}$ & $\begin{array}{c}\text { (MCS) } \\
\text { KSA } \\
\end{array}$ & $\begin{array}{l}\text { (MPM) } \\
\text { S. Korea } \\
\end{array}$ & $\begin{array}{l}\text { (PSC) } \\
\text { Canada } \\
\end{array}$ & $\begin{array}{c}\text { (OPM) } \\
\text { USA }\end{array}$ & Comparison \\
\hline Performanc & Performance & Performance & Performance & Performance & Performance & Named \\
\hline e Appraisal & Management & Management & Management & Management & Management & System \\
\hline $\begin{array}{l}\text { All staff, } \\
\text { except for } \\
\text { the } \\
\text { occupants } \\
\text { the of } \\
\text { special } \\
\text { functions, } \\
\text { experts and } \\
\text { advisers } \\
\text { class }\end{array}$ & $\begin{array}{l}\text { All staff of the } \\
\text { degree of } \\
\text { Undersecretary } \\
\text { of the Ministry } \\
\text { '(to class (10 } \\
\text { except for } \\
\text { grades (11) to } \\
\text { (14) }\end{array}$ & $\begin{array}{l}\text { All staff of } \\
\text { mattresses (13) } \\
\text { and below, } \\
\text { except for the } \\
\text { favorites (15) } \\
\text { (and (13 }\end{array}$ & $\begin{array}{l}\text { All staff, } \\
\text { senior including } \\
\text { civil service } \\
\text { officials }\end{array}$ & $\begin{array}{l}\text { All employees } \\
\text { in the public } \\
\text { service }\end{array}$ & $\begin{array}{l}\text { All } \\
\text { organizational } \\
\text { levels }\end{array}$ & $\begin{array}{l}\text { From subject } \\
\text { to } \quad \text { this } \\
\text { ?system }\end{array}$ \\
\hline 3 & 4 & 2 & 2 & 2 & 2 & $\begin{array}{l}\text { Number of } \\
\text { models used } \\
\text { in the system }\end{array}$ \\
\hline $\begin{array}{l}\text { Specific } \\
\text { elements } \\
\text { with } \\
\text { functional } \\
\text { performanc } \\
\text { e evaluation } \\
\text { system }\end{array}$ & $\begin{array}{l}\text { Objectives and } \\
\text { a set of } \\
\text { competencies }\end{array}$ & $\begin{array}{l}\text { Objectives and } \\
\text { a set of } \\
\text { competencies }\end{array}$ & $\begin{array}{l}\text { Objectives and } \\
\text { a set of } \\
\text { competencies } \\
\text { and plan } \\
\text { learning and } \\
\text { development }\end{array}$ & $\begin{array}{l}\text { Objectives and } \\
\text { a set of } \\
\text { competencies }\end{array}$ & $\begin{array}{l}\text { Objectives and } \\
\text { a set of } \\
\text { competencies }\end{array}$ & $\begin{array}{l}\text { The main } \\
\text { elements of } \\
\text { the system }\end{array}$ \\
\hline 1 & 3 & 3 & 3 & 3 & 5 & $\begin{array}{l}\text { Number of } \\
\text { stages of the } \\
\text { system }\end{array}$ \\
\hline 0 & 9 & 7 & 6 & 6 & 5 & $\begin{array}{l}\text { Number of } \\
\text { existing } \\
\text { competencies } \\
\text { in the system }\end{array}$ \\
\hline No & Yes & Yes & Yes & Yes & Yes & $\begin{array}{l}\text { Employee } \\
\text { sign the } \\
\text { valuation } \\
\text { model }\end{array}$ \\
\hline Secrecy & $\begin{array}{l}\text { confidenti-Non } \\
\text { al }\end{array}$ & $\begin{array}{l}\text { confidenti-Non } \\
\text { al }\end{array}$ & $\begin{array}{l}\text { confidenti-Non } \\
\text { al }\end{array}$ & $\begin{array}{l}\text { confidenti-Non } \\
\text { al }\end{array}$ & $\begin{array}{l}\text { confidenti-Non } \\
\text { al }\end{array}$ & $\begin{array}{l}\text { Evaluation } \\
\text { results }\end{array}$ \\
\hline 1 & 6 & 3 & $\begin{array}{l}\text { Manual } \\
\text { Performance } \\
\text { Agreement and } \\
\text { Policy } \\
\text { Performance } \\
\text { Management }\end{array}$ & $\begin{array}{l}\text { A large number } \\
\text { of pilot } \\
\text { evidence }\end{array}$ & $\begin{array}{l}\text { integrated An } \\
\text { library } \\
\text { manuals, } \\
\text { brochures, } \\
\text { instructions and } \\
\text { videos }\end{array}$ & $\begin{array}{l}\text { The number } \\
\text { of } \\
\text { methodologie } \\
\mathrm{s} \text { and } \\
\text { manuals that } \\
\text { came with the } \\
\text { system }\end{array}$ \\
\hline
\end{tabular}

Source: (Kong, D. et al, 2013), (Kim, Pan, 2014), (OPM, 2017), (MPA, 2018), (TBCS, 2014).

Through previous comparison based on performance evaluation systems on efficiency, draw some of the general principles and orientations that must be based on the evaluation of any functional performance of the civil service system, as follows:

1- The application of modern systems of performance evaluation is the most important " System Performance Management. "Where most of the literature suggests that it has become the modern approaches that have sprung up recently. (L. Spencer, \& S. Spencer, 1993), (Rashid, 2004), (Pulakos, 2004), (Aguinis, 2013), (Dorsy \& Hason, 2017)

2- Transparency and justice through the involvement of the government agency staff and inform them of all phases of the evaluation system and its components and competencies related to various organizational levels is. Research has shown that it is important to recognize that staff performance management system that is fair and transparent (Aguinis, 2013)

3- $\quad$ The system is flexible and easy application and connect them electronically with human resources information systems. A poll conducted by the Foundation Watson Wyatt Three out of every ten employees agree that the performance management system helps the organization to improve its performance, and that less than $40 \%$ said that performance management systems have developed clear performance targets, and the results also indicate that there is a weakness in the design of modern systems of performance in many organizations and 
performance management systems have become cumbersome because of the bureaucratic and time-consuming without any added value from their application. (Pulakos, 2004).

4- Linking the results of performance evaluation of other functions for the management of human resources Kaltrkiet, training, bonuses and other system.

The reforms related to performance based on the efficiency of the civil service in Oman assessment, relating to the transition from the current traditional methodology in the evaluation to " System Performance Management "With the need to focus on the preparation of the pilot guides the system by the Ministry of Civil Service, and the training of managers and officials of human resources on the system by the Institute of Public Administration.

\section{Competency Model / Framework}

Uses competency model Synonym competency framework It is a descriptive tool that includes skills, knowledge, personality traits and abilities and behavior are clear and detailed staff in the organization, and is considered very necessary to achieve strategic objectives and business successfully, and the framework for assessing the quality of human capital from the perspective of the organization's needs, and therefore the successful application of the concept of competencies in the organization conditional on providing process solutions field-based human resources management efficiency through efficiency models or frameworks (Hamid, 2014), (Sienkiewicz, 2014) .

This requires undertaking various measures can be classified into four categories, namely, (determining efficiency, competency assessment, gain efficiency, the use of efficiency) Initially, the institution you need to discover the competencies possessed by either the individual or organizational level, because they serve as a basis for the development of future talent, and more importantly, what are the competencies they need to improve institutional performance. (Rousku, 2014) The Orbiter system of talent management finds that there are many models and tire-related competencies, whether those models to government institutions or private, or professional associations or institutes and institutions consulting, or specialists in the field for researchers, but the important question how you can prepare those models or frameworks?

Since all comparison countries had developed its own set of competencies within the framework of core competencies or leadership or specialist, except for the civil service in the Sultanate of Oman, we do not recommend the reproduction of a window or a particular model and its application in the civil service, and we recommend conducting an integrated study using methodologies and methods of preparation model or competency framework which Oferdtha literature. And Figure 2 illustrates the stages and steps of the preparation of a form or a competency framework, it has been prepared based on different methodologies and studies.

\section{Conclusion}

As indicated previously, that the civil service reform is one of the most difficult development reforms, but efforts by governments and international organizations, and researchers seeking to overcome these difficulties, bridging research gaps, and development solutions, various scientific methodologies, and still continuing. Valtteri towards reform in the civil service needs time, and to the vision and a clear strategy, and cooperation between the various government agencies, in addition to supporting the adoption and applied research projects.

The construction of an integrated system for the management of competencies is important to move to a talent management system steps, and if implemented properly it will achieve the best results of government performance, and promotes the competitiveness of the public sector, and improves government services, and to achieve justice among employees. We hope to take the proposals contained in this article effectively, and that efforts are harnessed to do more research and studies in talent management and talent in the public sector. 


\begin{tabular}{|c|c|c|}
\hline $\begin{array}{c}1 \\
\text { Purpose \& Goal }\end{array}$ & $\begin{array}{l}\text { - } \quad \text { Identify Target and goal. } \\
\text { - Target Functional } \\
\text { Categories. } \\
\text { - Alignment with vision and } \\
\text { strategy. }\end{array}$ & $\begin{array}{l}\text { Processing of necessary } \\
\text { documents (Laws, regulations, } \\
\text { human resources systems and } \\
\text { policies, organizational } \\
\text { structure, job descriptions). }\end{array}$ \\
\hline $\begin{array}{c}2 \\
\text { Methodology \& Analysis }\end{array}$ & $\begin{array}{ll}\text { - } & \text { Traditional way. } \\
\text { - } & \text { professional Way. } \\
\text { - } & \text { The Integrated method. } \\
\text { - } & \text { Data collection and analysis. }\end{array}$ & $\begin{array}{l}\text { Interviews, questionnaires, } \\
\text { behavioral events, task } \\
\text { analysis, direct observation, } \\
\text { ready models. }\end{array}$ \\
\hline $\begin{array}{c}3 \\
\text { Readiness \& design }\end{array}$ & $\begin{array}{ll}\text { - } & \text { Competency Verification } \\
\text { - } & \text { Form Design } \\
\text { - } & \text { Form Markup }\end{array}$ & $\begin{array}{l}\text { Verified by (interviews, tests, } \\
\text { evaluation centers). } \\
\text { Using Performance indicators. }\end{array}$ \\
\hline $\begin{array}{c}4 \\
\text { Sharing \& implementation }\end{array}$ & $\begin{array}{ll}\text { - } & \text { Staff and management } \\
\text { problems. } \\
\text { - } & \text { Effective communication. } \\
\text { - } & \text { Dissemination of the model } \\
& \text { and provision of support. }\end{array}$ & $\begin{array}{l}\text { Induction lecture, training } \\
\text { programs and workshops } \\
\text { Guidance Guides. }\end{array}$ \\
\hline $\begin{array}{c}5 \\
\text { Continue } \& \text { Evaluation }\end{array}$ & $\begin{array}{ll}\text { - } & \text { Post-Implementation } \\
\text { Feedback. } \\
\text { - } \quad \text { Changes that may occur in } \\
\text { human resources systems. }\end{array}$ & $\begin{array}{l}\text { Questionnaires, interviews, } \\
\text { performance evaluation } \\
\text { results, change decisions and } \\
\text { documents. }\end{array}$ \\
\hline
\end{tabular}

Figure 2. Stages and steps of building a model or competency framework (L. Spencer, \& S. Spencer, 1993), (Orr, E, 2010), (Rousku, 2014), (MCS, 2015)

\section{References}

Aberdeen, Group (2007). Competency management the link between talent management and optimum business results. August [on line] (date of consultation 12-5-2013) http://www.assess.co.nz/pages/AberdeenStudy.pdf.

Ali, A.. F., \& Mahmood, H. I. (2013). Management of Public Organization. Amman: Dar Ghaida'a Publishing \& Distribution.

Alkubaisi, A.(2005). Human Resources Management in the Civil Service. Arab Administrative Development Organization. Cairo.

Aguinis, H. (2013). Performance management. Boston: Pearson.

Beeck, S., \& Hondeghem, A. (2010). Competency Management in the Public Sector: Three Dimensions of Integration Paper for the IRSPM Conference 2010. IRSPM Conference 2010.

Benayoune, A. (2017). Copetency-based framework: The benefits and the challenges. International Journal of Management and Applied Science, 3(9), 6-11.

Campion, M. A, \& Odman, R. B. (2011). Doing competencies well: Best practice in competency modelling. Personnel Psychology, 64, 225-262. https://doi.org/10.1111/j.1744-6570.2010.01207.x

Cho, Chang-hyun.(2010). Professional Civil Service of Korean Government. Republic of Korea Civil Service 
Commission, October, http://unpan1.un.org/intradocgroups/public/documents

De Beeck, S. O., \& Hondeghem, A. (2010). Managing Competencies in Government: State of the Art Practices and Issues at Stake for the Future. State of the Art Practices and Issues at Stake for the Future, 1-129. Retrieved from papers2://publication/uuid/7571753A-B9CD-4DE5-B552-96B435DBD8AE

Delamare, F., Le D., \& Jonathan, W. (2007). What Is Competence? Journal Human Resource Development International, 8(1), 27-46. https://doi.org/10.1080/1367886042000338227

Draganidis, F., \& Mentzas, G. (2006). Competency based management: a review of systems and approaches. Information Management \& Computer Security, 14(1), 51-64. https://doi.org/10.1108/09685220610648373

Dorsy, D., \& Hason, M.(2017). Performance Management That Makes A Difference: An Evidence-Based Approach. The Society for Human Resource Management (SHRM),

https://www.shrm.org/hr-today/trends-and-forecasting/special-reports-and-expert-views/Documents/Perfor mance\%20Management.pdf

FAHR. (2017). Federal Authority For Government Human Resources Strategic. Emirates. https://www.fahr.gov.ae/Portal/Userfiles/Assets/Documents/187b791b.pdf

Hamid, A. (2014). Development of an HR Practitioner Competency Model and Determining the Important Business Competencies : An Empirical Study in Malaysia. International Journal of Management Excellence 3(2), 446-461. https://doi.org/10.17722/ijme.v3i2.167

Hurley. J. (2017). Highlights of the history of the Public Service, www.canada.ca.

Gangani, N. T., McLean, G. N., \& Braden, R. A. (2006). A Competency-Based Human Resource Development Strategy. Performance Improvement Quarterly, 19, 127-139. https://doi.org/10.1111/j.1937-8327.2006.tb00361.x

IPMA-HR. (2016). HR2020 Shifting Perspectives: A Vision for Public Sector HR. International Public Management Association for Human Resources.

https://www.ipma-hr.org/docs/default-source/public-docs/importdocuments/node-documents/30655-hr-taskf orce-report-final

Kupczyk, T. (2014). Competencies of management Staff in the Knowledge-Based Economy.pdf.

Kim, P. (2014). Performance Appraisal and Performance-Related Pay in Government: The Case of South Korea. International Journal of Civil Service Reform and Practice (IJCSRP), 4. https://www.astanahubjournal.org/index.php/ijcsrp/article/view/14/14

Kim, S., \& Jung, H. W. (2010). The competency Management in the Korean National Government. K.U. Leuven, Public Management Institute, https://soc.kuleuven.be/io/onderzoek/project/files/hrm27-country-report-korea.pdf.

Kong, D., Kim, S., \& Yang, S. (2013). Individual performance appraisal in the government of Korea. KDI School of Public Policy and Management. Seoul, file://C:/Users/saqar\%201/Downloads/17\%20Government\%20HR\%20Policy.pdf

Laakso-Manninen, R., \& iitala, R. (2007). Competence management and human resources development: A theoretical framework for understanding the practices of modern Finnish organisations. HAAGA-HELIA Research. $\quad$ Retrieved from http://www.haaga-helia.fi/sites/default/files/Kuvat-ja-liitteet/Palvelut/Julkaisut/hrdweb.pdf

Lafuente,M. Manning, N. Watkins, J. (2012).International Experiences with Senior Executive Service Cadres. Global Expert Team on Public Sector Performance (PSP GET), The World Bank, April, P 1-16, http://siteresources.worldbank.org/EXTGOVANTICORR/Resources/3035863-1285601351606/GET_Note_ Recently_Asked_Questions_Senior_Executive_Services.pdf

L. Spencer, \& S. Spencer. (1993). Competence at Work: Model for Superior Performance. John Wiley \& Sons, New York.

Lynch, K. G. (2009). Sixteenth Annual Report to the Prime Minister on the Public Service of Canada. Privy Council Office, http://publications.gc.ca/collections/collection_2010/bcp-pco/CP1-1-2009-eng.pdf.

McClelland, D. C. (1973). Testing for competence rather than for "intelligence." American Psychologist, 28(1), 1-14. https://doi.org/10.1037/h0034092

MCS. (2015). competency Framework- Guideline. Ministry of Civil Service, Kingdom of Saudi Arabia, August, 
https://www.mcs.gov.sa

MPM. (2018). Annual Report 2017. Ministry of Personnel Management. September, file:///C:/Users/saqar\%201/Downloads/Ministry\%20of\%20Personnel\%20Management\%202017\%20Annual $\% 20$ Report\%20(1).pdf

MPM. (2018). Public Human Resource Management At a Glance 2018. Ministry of Personnel Management. South Korea, http://www.mpm.go.kr/english/news/Multimedia/ebook/hrm/hrm2018/

MSPB. (2017). The Merit System Principles : Keys to Managing the Federal Workforce. Merit Systems Protection Board. United States, January,

https://www.mspb.gov/mspbsearch/viewdocs.aspx?docnumber=1371890\&version=1377261

MSPB. (2004). Managing Federal Recruitment: Issues, Insights, and Illustrations. Merit Systems Protection Board. United States, September, https://www.mspb.gov.

Namkoong, K. (2007). Civil Service Reform in Participatory Government : Civil Service System in Transition. The Korean Journal of Policy Studies, 22(1), 19-45.

OECD. (2017). Staff performance management in Government at a Glance 2017. OECD Publishing. Paris, DOI: https://doi.org/10.1787/gov_glance-2017-46-e

OECD. (2015). Dominican Republic : Human Resource Management for Innovation in Government.OECD Public Governance Reviews, 1-372.

http://www.oecd.org/publications/dominican-republic-human-resource-management-for-innovation-in-gove rnment-9789264211353-en.htm

OCHRO. (2015). Key Leadership Competencies: Examples of Effective and Ineffective Behaviors.Office of the Chief Human Resources Officer. Treasury Board of Canada Secretariat, June.

Okoth, S., \& Ph, D. (2015). A Review of State of the Art of Public Administration in Western Academia Lessons for the Gulf States A Review of State of the Art of Public Administration in Western Academia, 1, 1-20.

OPM. (2018). OPM Strategic Plan Fiscal Years 2018 - 2022. Office of Personnel Management. United States, https://www.opm.gov/about-us/budget-performance/strategic-plans/2018-2022-strategic-plan.pdf

OPM. (2017). A Handbook for Measuring Employee Performance. Office of Personnel Management. United States, March.

https://www.opm.gov/policy-data-oversight/performance-management/measuring/employee_performance_ handbook.pdf

OPM. (n.d). Federal Human Capital Business Reference Model (HCBRM) Office of Personnel Management. United States.

https://www.opm.gov/services-for-agencies/hr-line-of-business/hc-business-reference-model/hc-brm-interac tive-model.pdf.

Oman 2040. (n.d) Improving Governance Effectiveness. https://2040.om/en/governance-and-institutional-performance/

Orr, E., Dai, G., \& Senetljes, C. (2010). The Art and Science of Competency Modeling :Best Practices in Developing and Implementing Success Profiles. Korn Ferry Institute, Los Angeles, https://www.kornferry.com/institute/the-art-and-science-of-competency-modeling-best-practices-in-develop ing-and-implementing-success-profiles

Prasanthi, S. (2015). Competency Based HRM. International Journal in Management and Social Science, 3(1), 135-145.

Peregrin, T. (2014). Competency-Based Hiring: The Key to Recruiting and Retaining Successful Employees. JAND, 114(9), 1330-1331,1332-1335,1337,1339. https://doi.org/10.1016/j.jand.2014.07.016

PSC. (2017). Public Service Today: Annual Report 2016-17. Public Service Commission of Canada, https://www.canada.ca/content/dam/psc-cfp/documents/publications/annual-report/ar2017-en.pdf

Pulakos, E. D. (2004). Performance Management: A roadmap for developing, implementing and evaluating performance management systems. The Society for Human Resource Management(SHRM), https://www.shrm.org/hr-today/trends-and-forecasting/special-reports-and-expert-views/Documents/Perfor mance-Management.pdf

R, Boyatzis. (1982). The Competent Manager : A Model for Effective Performance, John Wiley \& Sons, New 
York.

Rashid, M.(2004). Human Resourses Management, Obekan Book Store, Riyadh.

Sienkiewicz, Ł. (2014). Competency-based human resources management The lifelong learning perspective. Educational Research Institute.

Rousku, A. (2014). Competence Identification Assessment \& Development : Study Merivaara Oy. Master's Degree programs in International Business Administration Thesis, Lahti University of Applied Sciences, P1-88, https://www.theseus.fi/bitstream/handle/10024/85126/Rousku_Anu.pdf?sequence=1

Rosenberg. DeAnne.(2000). A Manager's Guide to Hiring the Best Person for Every Job. John Wiley \& Sons, Inc.

Shafritz, J. M., \& Hyde, A. C. (2012). Classics of public administration. Australia: Wadsworth/Cengage Learning.

Sabbarah. (2013).International Practices in Selection, Assessment, and Use of General Cognitive Ability Tests. Sabbarah for Eductional Evaluation \& Testing. December, https://www.mcs.gov.sa/ASCSP/StudiesResearch/PublishingImages/International\%20Practices\%20in\%20S eletion,\%20Assessment,\%20and\%20use\%20of\%20Genaral\%20Cognitive\%20Ability\%20Tests.pdf

TBCS. (2014). Implementing Performance Management Programs. Treasury Board of Canada Secretariat, https://www.tbs-sct.gc.ca.

Timothy, R., Athey, M., \& Orth, S. (1999). Emerging competency methods for the future. Human Resource Management, 38(3), 215-226. https://doi.org/10.1002/(SICI)1099-050X(199923)38:3<215::AID-HRM4>3.0.CO;2-W

United Nations. (2013). Human Development Report 2013, The Rise of the South: Human Progress in a Diverse World. http://hdr.undp.org/sites/default/files/reports/14/hdr2013_en_complete.pdf

United Nations. (2005). Human Resources for Effective Public Administration in a Globalized World. Department of Economic and Social Affairs, https://publicadministration.un.org/publications/content/PDFs/E-Library\%20Archives/2005\%20Human\%20 Resources\%20for\%20Effective\%20Public\%20Administration\%20in\%20a\%20Globalized\%20World.pdf

UNDP. (2015). Meritocracy for Public Service Excellence. United Nations Development Programme. Global Centre for Public Service Excellence, Singapore, \& Regional Hub of Civil Services in Astana, Kazakhstan, http://www.undp.org/content/dam/undp/library/capacity-development/English/Singapore\%20Centre/Merito cracy-PSE.pdf

UNDP. (2010). Motivating Civil Servants for Reform and Performance. United Nations Development Programme,https://orbi.uliege.be/bitstream/2268/37467/1/Motivating\%20Civil\%20Servants\%20for\%20Ref orm\%20and\%20Performance.pdf

Walle, S., Van De, \& Brans, M. (2018). Where Comparative Public Administration and Comparative Policy Studies Meet Where Comparative Public Administration and Comparative Policy Studies Meet. Journal of Comparative Policy Analysis: Research and Practice, 20(1), 101-113. https://doi.org/10.1080/13876988.2017.1411006.

Weinert, F. E. (1999) Concepts of Competence, Definition and Selection of Competencies, April, Retrieved from http://citeseerx.ist.psu.edu/viewdoc/download?doi=10.1.1.111.1152\&rep=rep1\&type=pdf

World Resource Institute (2008). Earth Trends the Environment Information Portal : Government Effectiveness Index 2008, www.wri.org.

\section{Copyrights}

Copyright for this article is retained by the author(s), with first publication rights granted to the journal.

This is an open-access article distributed under the terms and conditions of the Creative Commons Attribution license (http://creativecommons.org/licenses/by/4.0/). 